\title{
Meningkatkan Kemandirian Anak Melalui Kegiatan Practical Life Skill
}

\author{
Nina Kurniawati ${ }^{1}$, Tuti Hayati ${ }^{2}$
}

${ }^{1 .}$, ${ }^{3}$ Pendidikan Islam Anak Usia Dini UIN Sunan Gunung Djati Bandung

Jalan Cimencrang, Gede Bage, Kota Bandung, Jawa Barat, 40282

Email:kurnianina282@gmail.com ${ }^{1}$,Hayatituti@yahoo.co.id ${ }^{2}$

Naskah diterima: 22 Desember 2019, direvisi: 23 Maret 2020, diterbitkan: 31 Maret 2020

\begin{abstract}
Abstrak
Observasi awal dilakukan pada anak kelompok A RA Yapata Al-Jawami bahwa kemandirian anak masih rendah. Hal ini terbukti dalam kegiatan makan masih dibantu orang tua atau guru sekolah. Tujuan penelitian ini untuk mengetahui penerapan kegiatan practical life skill untuk meningkatkan kemandirian anak. Metode yang digunakan adalah Penelitian Tindakan kelas. Metode tersebut meliputi: perencanaan, tindakan, pengamatan dan refleksi. Teknik pengumpulan data melalui observasi, unjuk kerja dan dokumentasi. Adapun hasil penelitian bahwa kemandirian anak sebelum diterapkan kegiatan practical life skill diperoleh nilai rata-rata sebsesar 44,76 dengan kriteria kurang sekali. Penerapan kegiatan practical life skill untuk meningkatkan kemandirian anak mengalami peningkatan. Hal ini dapat dilihat dari aktivitas guru pada siklus I diperoleh nilai rata-rata sebesar 71,5\% dengan kriteria cukup dan pada siklus II diperoleh nilai rata-rata sebesar 88,72\% dengan kriteria sangat baik, sedangkan aktivitas anak pada siklus I diperoleh nilai rata-rata sebesar 58,95\% dengan kriteria kurang dan pada siklus II diperoleh nilai rata-rata sebesar 76,82\% dengan kriteria baik. Selanjutnya kemandirian anak pada kegiatan practical life yaitu siklus I diperoleh nilai rata-rata sebesar 55,94 dengan kriteria kurang dan pada siklus II diperoleh nilai rata-rata sebesar 75,35 dengan kriteria baik. Dengan demikian hipotesis yang diajukan diterima, artinya kegiatan practical life skill dapat meningkatkan kemandirian anak.
\end{abstract}

Kata kunci: Anak Usia Dini, Kemandirian, Practical Life Skill.

\author{
Abstract \\ Preliminary observations were made on children of group A $\mathrm{R} A$ Yapata Al-Jawami that children's \\ independence was still low. This is evident in the eating activities still assisted by parents or school teachers. \\ The purpose of this study is to find out the application of practical life skills activities to improve children's
}


independence. The method used is classroom action research. These methods include: planning, action, observation and reflection. Techniques for collecting data through observation, performance and documentation. The results of the study that the independence of children before being applied to practical life skills activities obtained an average value of 44.76 with very few criteria. The application of practical life skills activities to improve children's independence has increased. This can be seen from the activity of the teacher in the first cycle obtained an average value of $71.5 \%$ with sufficient criteria and in the second cycle obtained an average value of $88.72 \%$ with very good criteria, while the activity of children in the first cycle obtained a value an average of $58.95 \%$ with less criteria and in the second cycle obtained an average value of $76.82 \%$ with good criteria. Furthermore, the independence of children in practical life activities, namely cycle I obtained an average value of 55.94 with less criteria and in the second gycle obtained an average value of 75.35 with good criteria. Thus the proposed hypothesis is accepted, meaning that practical life skills activities can improve children's independence.

Keywords: Early childhood, Independence, Practical Life Skill.

\section{Pendahuluan}

Anak adalah anugerah yang paling berharga bagi orang tuanya. Oleh sebab itu sebagai orang tua harus memberikan teladan, didikan serta arahan yang baik kepada anak, karena sejatinya anak mudah meniru sikap orang tua, jika orang tuanya memberi teladan yang tidak baik mana tidak menutup kemungkinan anaknya berbuat tidak baik pula. Sebagaimana pendapat Al-Ghazali bahwa anak-anak adalah amanah bagi kedua orangtuanya, dan hatinya yang suci adalah permata yang sangat mahal harganya. Karenanya, jika dibiasakan pada kebaikan dan diajarkan kebaikan kepadanya, maka anak akan tumbuh pada kebaikan tersebut, dan akan berbahagialah di dunia dan akhirat (Yusuf, 2008: 10).

Dalam Undang-Undang No 20 Tahun 2003 dijelaskan bahwa pendidikan anak usia dini adalah suatu upaya pembinaan yang ditujukan kepada anak sejak lahir sampai usia 6 tahun yang dilakukan dengan pemberian rangsangan pendidikan untuk membantu pertumbuhan dan perkembangan jasmani agar anak memiliki kesiapan dalam memasuki pendidikan lebih lanjut, baik pendidikan secara formal di sekolah maupun secara nonformal. Pendidikan anak usia dini merupakan salah satu bentuk penyelenggaraan pendidikan yang menitikberatkan pada peletakan dasar ke beberapa arah pengembangan. Dalam Peraturan Menteri Pendidikan Nasional No 58 Tahun 2009 dijelaskan bahwa aspek yang dikembangkan dalam pendidikan anak usia dini adalah aspek perkembangan perilaku 
dan pembiasaan meliputi sosial, emosi, kemandirian, nilai agama, dan moral serta pengembangan bahasa, kognitif, seni, dan fisik motorik.

Salah satu aspek perkembangan yang perlu dikembangkan pada anak sejak dini adalah kemandirian. Brawer dalam Komala (2015: 32) mengatakan bahwa kemandirian Taman Kanak-Kanak/Raudhatul Athfal indikatornya adalah pembiasaan yang terdiri dari kemampuas fisik, percaya diri, bertanggung jawab, disiplin, pandai bergaul, mau berbagi, dan mengendalikan emosi. Istilah kemandirian pada anak umumnya dikaitkan dengan kemampuan untuk melakukan segala sesuatunya sendiri, tanpa harus tergantung pada orang lain (Hogg \& Blau dalam Suseno, 2012: 1).

Mandiri dalam bentuk yang paling dikenal meliputi aktivitas sehari-hari dalam rangka membantu diri sendiri. Misalnya makan sendiri, mandi sendiri, memakai dan melepaskan pakaian sendiri, memakai dan melepaskan sepatu sendiri. Namun, bila dilihat lebih jauh, kemandirian berkaitan erat dengan kemampuan meyelesaikan masalah, yaitu: mengambil inisiatif, mengatasi masalah sehari-hari, tekun, serta ingin melakukan sesuatu tanpa bantuan orang lain. Maka tidak heran apabila kemandirian akan berdampak positif bagi anak, menjadi bekal hidupnya kelak saat anak harus berinteraksi dengan orang lain dan terjun di masyarakat (Rakhma, 2017: 29).

Kenyataan di lapangan ketika peneliti melakukan pengamatan pada kelompok A RA Yapata Al-Jawami Cileunyi Bandung bahwa kemandirian anak masih rendah, terutama dalam kegiatan makan. Pada saat kegiatan makan anak masih memerlukan bantuan orang tua seperti mengambil makanan di dalam tas, meminta guru membuka botol minuman, membuka bungkus kue, bahkan setelah makan sebagian anak langsung ke luar kelas untuk bermain tanpa membereskan tempat makanan dan minuman, setelah bermain anak sering membiarkan mainan berserakan di lantai tanpa menyimpan kembali pada tempatnya.

Practical life skill merupakan salah satu bagian dari pendekatan Montessori untuk anak usia dini. Pada pendekatan ini anak akan belajar melakukan aktivitas-aktivitas yang kerap dilakukan dalam kegiatan sehari-hari dan hal ini sangat mudah dilakukan anak untuk bekal hidupnya di kemudian hari. Sebagaimana pendapat Isjoni dalam Rohmah (2009: 4) practical life adalah suatu kegiatan kehidupan sehari secara langsung dalam proses pembelajaran pembekalan ketrampilan hidup (life skill) pada anak usia dini dalam peningkatan kemandirian anak. 
Salah satu cara untuk meningkatkan kemandirian anak melalui keterampilan hidup praktis (practical life skill) dari pendekatan Montessori. Melalui kegiatan practical life skill anak diharapkan bisa mandiri dalam melakukan kegiatan sehari-hari dan dalam memenuhi kebutuhannya. Berdasarkan fenomena-fenomena yang diungkapkan di atas, peneliti tertarik untuk mengadakan penelitian melalui sebuah judul "Kemandirian Anak Melalui Kegiatan Practical Life Skill". Tujuan yang ingin dicapai dalam penelitian ini adalah untuk meningkatkan kemandirian anak melalui kegiatan practical life skill pada anak kelompok A RA Yapata Al-Jawami Cileunyi Bandung.

\section{Metodologi}

Penelitian ini dilakukan di RA Yapata Al-Jawami yang berada di Komplek Pesantren Al-Jawami No. 85 Cileunyi Bandung. Penelitian ini dilakukan di kelompok A RA Yapata Al-Jawami pada semester I Tahun Ajaran 2018/2019. Waktu penelitian tindakan kelas ini dilaksanakan pada tanggal 17 Juli - 15 November 2018. Subjek penelitian sebanyak 15 anak.

Pendekatan dalam penelitian ini menggunakan pendekatan kombinasi. Johnson dan Cristensen (Sugiyono, 2018: 404) mengatakan bahwa penelitian kombinasi merupakan pendekatan dalam penelitian yang mengkombinasikan atau menghubungkan antara metode penelitian kuantitatif dan kualitatif. Hal itu mencakup landasan filosofis, penggunaan pendekatan kualitatif dan kuantitatif, dan mengkombinasikan kedua pendekatan dalam penelitian.

Metode yang digunakan dalam penelitian ini adalah penelitian tindakan kelas. Menurut Kemmis (Sanjaya, 2009: 24) penelitian tindakan kelas adalah suatu bentuk penelitian reflektif dan kolektif yang dilakukan oleh peneliti dalam situasi sosial untuk meningkatkan penalaran praktik sosial mereka. Dalam PTK terdapat beberapa model yang sampai saat ini masih digunakan dalam dunia pendidikan. Beberapa ahli mengungkapkan model penelitian tindakan dengan bagan yang berbeda, namun secara garis besar terdapat empat tahapan, yaitu planning (perencanaan) action (tindakan) observasi (pengamatan) refleksi (Arikunto, 2012: 16).

Adapun bagan dari alur penelitian tindakan kelas (PTK) ini adalah sebagai berikut: 


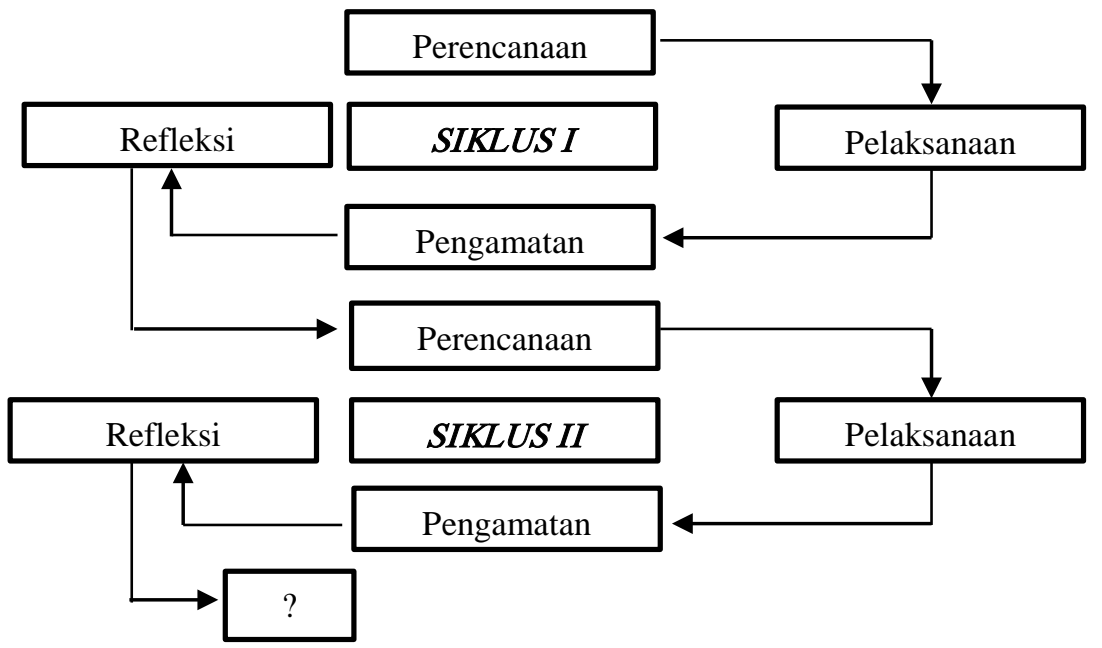

Gambar 1. Siklus Penelitian Tindakan Kelas

Jenis data yang digunakan dalam penelitian ini adalah data kualitatif dan data kuantitatif. Data kualitatif diperoleh dari data hasil observasi dan dokumentasi. Sedangkan data kuantitatif adalah data yang telah terkumpul dan dianalisis dengan menggunakan statistik deskriptif sehingga dapat disimpulkan hipotesis yang dirumuskan terbukti atau tidak (Sugiyono, 2015: 15). Data kuantitatif dalam penelitian ini berupa data dari hasil unjuk kerja kemandirian anak dengan kegiatan practical life skill.

Teknik pengumpulan data dalam penelitian ini menggunakan teknik observasi, unjuk kerja, dan dokumentasi. Observasi merupakan pengamatan dan pencatatan secara sistematis terhadap gejala yang tampak pada objek penelitian (Zuriah, 2007: 173). Pengamatan dan perencanaan ini dilakukan terhadap objek di tempat terjadi atau berlangsungnya peristiwa. Observasi ini dilakukan untuk mengamati aktivitas guru dan anak. (2) Unjuk kerja merupakan skor yang diperoleh dari pengamatan yang dilakukan terhadap penampilan peserta didik dari suatu kompetensi (Hayati, 2013: 49). Instrumen unjuk kerja ini bertujuan untuk mengetahui sejauh mana peningkatan kemandirian anak pada kegiatan practical life skill dalam setiap siklus pembelajaran. Dokumentasi digunakan untuk mendokumentasikan peristiwa yang terjadi selama proses pembelajaran di kelas berupa foto guru yang sedang mengajar dan anak yang sedang melakukan kegiatan pembelajaran.

Analisis data yang diperlukan dalam penelitian ini adalah analisis data kualitatif dan kuantitatif. Analisis data secara kualitatif dilakukan terhadap pemerolehan data dari 
dokumentasi dan observasi. Data yang diperoleh bersifat naratif deskriptif sehingga data disajikan dalam bentuk kualitatif. Analisis data secara kuantitatif dilakukan dari hasil observasi dan penilaian unjuk kerja anak yang dilakukan secara individual di kelas yang bermaksud untuk mengukur kemandirian anak dengan kegiatan practical life skill. Cara perhitungannya sebagai berikut:

1. Analisis Data Observasi Aktivitas Guru dan Anak

Lembar observasi dapat dianalisis menggunakan rumus sebagai berikut:

$$
\mathrm{NP}=\frac{R}{S M} \times 100 \%
$$

Keterangan:

$\mathrm{NP}=$ Nilai persen yang dicari atau diharapkan

$\mathrm{R}=$ Skor mentah yang diperoleh Guru dan Anak

$\mathrm{SM}=$ Skor maksimum ideal dari yang bersangkutan

Setelah diperoleh jumlah aktivitas guru dan anak, kemudian dihitung rata-rata melalui rumus:

$$
\bar{x}=\frac{\sum \mathrm{X}}{\sum \mathrm{N}}
$$

Keterangan :

$\bar{x} \quad=$ Nilai rata-rata $($ mean $)$

$\sum \mathrm{X}=$ Jumlah semua nilai siswa

$\mathrm{N} \quad=$ Jumlah siswa

Nilai aktivitas yang diperoleh melalui rumus di atas, selanjutnya diinterpretasikian pada skala kualifikasi sebagai berikut:

Tabel 1. Skala Kualifikasi Penilaian

\begin{tabular}{ccc}
\hline No & Tingkat Penguasaan & Predikat \\
\hline 1 & $86-100 \%$ & Sangat Baik \\
2 & $76 \%-85 \%$ & Baik \\
3 & $60 \%-75 \%$ & Cukup \\
4 & $55 \%-59 \%$ & Kurang \\
5 & $0-54 \%$ & Kurang Sekali \\
\hline \multicolumn{3}{c}{ Sumber Purwanto, 2009: 103}
\end{tabular}

2. Perhitungan Kemandirian Anak, baik sebelum maupun setelah diterapkan kegiatan practical life skill melalui rumus sebagai berikut:

$$
\mathrm{KA}=\frac{\text { skor perolehan anak }}{\text { skor maksimal }} \times 100
$$

Keterangan:
$\mathrm{KA}$
$=$ Kemandirian Anak 
Jumlah skor maksimal $=$ jumlah skor kemandirian anak

Selanjutnya nilai tersebut diolah untuk menghasilkan nilai rata-rata anak yaitu dengan membagi jumlah seluruh skor yang diperoleh anak dibagi dengan jumlah anak. Adapun rumusnya adalah sebagai berikut:

$$
\bar{x}=\frac{\sum \mathrm{X}}{\sum \mathrm{N}} \quad \text { (Aqib, 2014: 40) }
$$

Keterangan :

$$
\begin{array}{ll}
\bar{x} & =\text { Nilai rata-rata (mean) } \\
\sum \mathrm{X} & =\text { Jumlah semua nilai siswa } \\
\mathrm{N} & =\text { Jumlah siswa }
\end{array}
$$

Nilai rata-rata anak digunakan untuk mengetahui nilai rata-rata kemandirian anak pada setiap siklus, dan digunakan sebagai bahan refleksi apabila pada suatu siklus kemandirian anak tidak meningkat. Setelah diperoleh nilai atau skor kemandirian setiap anak, kemudian diinterpretasikan pada skala kualifikasi sebagai berikut:

Tabel 2 Skala Kualifikasi Penilaian

\begin{tabular}{ccc}
\hline No & Tingkat Keberhasilan & Kriteria \\
\hline 1. & $80-100$ & Sangat baik \\
2. & $70-79$ & Baik \\
3. & $60-69$ & Cukup \\
4. & $50-59$ & Kurang \\
5. & $0-54$ & Kurang sekali \\
\hline & Sumber: Syah, 2012: 223
\end{tabular}

\section{Hasil dan Diskusi}

Berdasarkan analisis data hasil kemandirian anak sebelum melakukan kegiatan practical life skill pada pra siklus belum maksimal. Hal ini menunjukkan kemandirian anak diperoleh nilai sebesar 44,76 dengan kategori kurang sekali. Guru di sekolah kurang memanfaatkan kegiatan-kegiatan yang menunjang kemandirian anak. Hal ini terbukti dari hasil observasi awal yang dilakukan oleh penulis. Namun setelah diterapkan kegiatan practical life skill maka terjadi peningkatan kemandirian anak di kelompok A RA Yapata AlJawami Cileunyi Bandung.

Adapun penerapan kegiatan practical life skill untuk meningkatkan kemandirian anak kelompok A RA Yapata Al-Jawami Cileunyi Bandung yaitu pada siklus I dapat dilakukan melalui observasi aktivitas guru dan aktivitas anak yang terdiri dari dua tindakan. Adapun uraian aktivitas guru dan aktivitas anak sebagai berikut: Aktivitas guru pada proses 
pembelajaran dengan menerapkan kegiatan practical life skill pada siklus I tindakan I dengan perolehan presentase sebesar $66,67 \%$ dengan kriteria cukup dan siklus I tindakan II diperoleh nilai rata-rata 77,78\% dengan kriteria baik. Maka dihitung rata-rata hasil observasi aktivitas guru pada siklus I dalam tabel berikut:

Tabel 3 Rata-rata Hasil Observasi Aktivitas Guru Siklus I

\begin{tabular}{ccc}
\hline No & Tindakan & Hasil Observasi \\
\hline 1. & Tindakan pertama & $66,67 \%$ \\
2. & Tindakan Kedua & $77,78 \%$ \\
& Rata-rata & $72,22 \%$ \\
\hline
\end{tabular}

Berdasarkan perhitungan di atas, maka tingkat keterlaksanaan aktivitas guru pada siklus I adalah $72,22 \%$ dengan kriteria cukup, dengan demikian perlu ditingkatkan pada siklus II, agar aktivitas guru dapat meningkat. Sedangkan hasil observasi aktivitas anak pada siklus I tindakan I diperoleh nilai rata-rata pada aktivitas anak sebesar 54,15\% dengan kriteria kurang dan siklus I tindakan II diperoleh nilai rata-rata sebesar 63,75\% dengan kriteria cukup. Maka dihitung rata-rata hasil observasi aktivitas anak pada siklus I dalam tabel berikut:

Tabel 4 Rata-rata Hasil Observasi Aktivitas Anak Siklus I

\begin{tabular}{ccc}
\hline No & Tindakan & Hasil Observasi \\
\hline 1. & Tindakan Pertama & $54,15 \%$ \\
2. & Tindakan Kedua & $63,75 \%$ \\
& Rata-rata & $58,95 \%$ \\
\hline
\end{tabular}

Berdasarkan perhitungan di atas, maka tingkat keterlaksanaan aktivitas anak pada silkus I adalah 58,95 dengan kriteria cukup. Dengan demikian pembelajaran dilanjutkan pada siklus berikutnya. Sedangkan pada siklus II penerapan kegiatan practical life skill untuk meningkatkan kemandirian anak dapat dilakukan melalui observasi aktivitas guru dan aktivitas anak yang terdiri dari dua tindakan. Hasil aktivitas guru pada siklus II mengalami peningkatan dengan rincian pada siklus II tindakan I sebesar 83,33\% dengan kriteria baik dan siklus II tindakan II sebesar 94,44\% dengan kategori sangat baik. Maka dihitung ratarata hasil observasi aktivitas guru pada siklus II dalam tabel berikut:

Tabel 5 Rata-rata Hasil Observasi Aktivitas Guru Siklus II

\begin{tabular}{ccc}
\hline No & Tindakan & Hasil Observasi \\
\hline 1. & Tindakan pertama & $83,33 \%$ \\
2. & Tindakan Kedua & $94,44 \%$ \\
& Rata-rata & $88,88 \%$ \\
\hline
\end{tabular}


Berdasarkan perhitungan di atas, maka tingkat keterlaksanaan aktivitas guru pada silkus II adalah $88,88 \%$ dengan kriteria sangat baik. Maka dinyatakan aktivitas guru pada siklus II meningkat dari kriteria cukup menjadi sangat baik. Sedangkan aktivitas anak pada siklus II mengalami peningkatan dengan rincian siklus II tindakan I diperoleh nilai rata-rata sebsesar 72,91\% dengan kriteria baik dan siklus II tindakan II diperoleh nilai rata-rata sebesar $81,52 \%$ dengan kriteria sangat baik. Maka dihitung rata-rata hasil observasi aktivitas anak pada siklus II dalam tabel berikut:

Tabel 6 Rata-rata Hasil Observasi Aktivitas Anak Siklus II

\begin{tabular}{ccc}
\hline No & Tindakan & Hasil Observasi \\
\hline 1. & Tindakan Pertama & $72,13 \%$ \\
2. & Tindakan Kedua & $81,51 \%$ \\
\multicolumn{2}{c}{ Rata-rata } & $76,82 \%$ \\
\hline
\end{tabular}

Berdasarkan perhitungan di atas, maka tingkat keterlaksanaan aktivitas anak pada silkus II adalah 76,82\% dengan kriteria baik. Adapun kemandirian anak setelah diterapkan kegiatan practical life skill pada siklus I melalui unjuk kerja diperoleh nilai rata-rata 55,94 yang menunjukkan kriteria kurang. Perolehan nilai rata-rata pada siklus I tindakan pertama adalah 51,66 dan pada tindakan kedua 60,23 maka nilai rata-rata siklus I adalah 55,94 dengan kriteria kurang. Sedangkan Pada siklus II tindakan I kemandirian anak menunjukkan peningkatan. Hal ini terlihat dari sudah tidak adanya kriteria kurang dan kurang sekali. Pada siklus II tindakan II kemandirian anak menunjukkan peningkatan yang sangat signifikan. Hal ini terlihat dari tidak ada anak dalam kriteria kurang, kurang sekali dan cukup. Perolehan nilai rata-rata pada siklus II tindakan I adalah 70,23 dan pada tindakan II adalah 80,47 maka rata-rata nilai pada siklus II adalah 75,35 dengan kriteria baik. Perolehan data di atas dapat disimpulkan bahwa hasil aktivitas anak dan hasil unjuk kerja kemandirian anak melalui kegiatan practical life skill mengalami peningkatan. Dengan demikian hipotesis yang diajukan oleh peneliti diterima, artinya kegiatan practical life skill dapat meningkatkan kemandirian anak di kelompok A RA Yapata Al-Jawami Cileunyi Bandung.

Dalam pelaksanaan kegiatan practical life skill hal pertama yang dilakukan guru adalah mengajak anak untuk duduk melingkar, mengenalkan kegiatan practical life skill, anak mengambil makanan sendiri yaitu mengoleskan mentega dan seres ke atas roti pada siklus I tindakan I, membuat bola-bola susu pada siklus I tindakan II, membuat jagung susu keju 
pada siklus II tindakan I dan membuat pisang keju pada siklus II tindakan II. Adapun sebelum melakukan kegiatan tersebut guru terlebih dahulu memperlihatkan media yang disediakan lalu memperagakan cara-cara melakukan kegiatan. Setelah itu anak diberi kesempatan secara bergantian satu persatu untuk melakukan kegiatan. Pada kegiatan practical life skill ini anak belajar melakukan aktivitas-aktivitas yang kerap dilakukan dalam kegiatan sehari-hari dan hal ini sangat mudah dilakukan untuk anak. Sebagaimana pendapat Montessori bahwa dalam kegiatan practical life skill anak akan belajar melakukan berbagai macam aktivitas dalam kegiatan sehari-hari yang merupakan bekal kemampuan hidup yang penting di kemudian hari.

Kegiatan practical life skill dapat melatih anak untuk mandiri dan mengurus dirinya sendiri. Jika guru membiasakan anak melakukan kegiatan makan sendiri mulai dari mencuci tangan sendiri sebelum makan, mengambil makanan sendiri, sampai berdoa sesudah makan, lama-lama anak akan terbiasa melakukannya meskipun tidak disuruh orang lain. Kemampuan mengurus dirinya sendiri merupakan proses pembelajaran dan perlahan-lahan menjadikan anak lebih mandiri dalam menghadapi kehidupannya setelah dewasa kelak.

Penelitian ini sejalan dengan penelitian sebelumnya yang dilakukan oleh Maria Putri Setyaningsih mahasiswa Insitut Agama Islam Negeri Surakarta yang berjudul "Penggunaan Media Loker Siswa untuk Meningkatkan Kemandirian Anak Kelas B TK Pertiwi Ngaran II Polanharjo Klaten" Hasil penelitiannya menunjukkan penggunaan media loker siswa dapat meningkatkan kemandirian anak. Dalam penelitian ini loker siswa digunakan sebagai media untuk menarik perhatian anak dalam meningkatkan kemandiriannya. Maka dari itu loker siswa dibuat semenarik mungkin supaya anak mau menggunakannya. Pada kondisi awal atau pra siklus sebesar 56,25\% pada siklus I sebesar 62,3\% dan pada siklus II sebesar $87,5 \%$. Dengan demikian kemandirian anak mengalami peningkatan pada setiap siklusnya.

\section{Penutup}

Berdasarkan hasil analisis data tentang kegiatan practical life skill untuk meningkatkan kemandirian anak usia dini di kelompok A RA Yapata Al-Jawami Cileunyi Bandung dapat disimpulkan sebagai berikut: (1) Kemandirian anak usia dini di kelompok A RA Yapata AlJawami Bandung sebelum dilakukan kegiatan practical life skill memperoleh nilai rata-rata sebesar 44,76 dengan kriteria kurang sekali, karena berada pada interval 0 - 54. (2) Proses kegiatan practical life skill dalam meningkatkan kemandirian anak usia dini sudah termasuk dalam kriteria baik. Hal ini terlihat dari pelaksanaan semua tahapan kegiatan practical life skill 
oleh guru dan anak. Aktivitas guru dan anak mengalami peningkatan setiap siklusnya. Nilai rata-rata aktivitas guru pada siklus I adalah 71,5\% dengan kriteria baik dan pada siklus II nilai rata-rata keterlaksanaan aktivitas guru sebesar $88,72 \%$ dengan kriteria sangat baik. Sedangkan aktivitas anak pada siklus I memperoleh nilai rata-rata sebesar 58,95\% dengan kriteria kurang dan pada siklus II nilai rata-rata aktivitas anak adalah 76,82\% dengan kriteria baik. (3) Kemandirian anak setelah dilakukan kegiatan practical life skill pada setiap siklusnya mengalami peningkatan. Hal ini dapat dilihat dari meningkatnya kemandirian anak melalui kegiatan practical life skill pada siklus I memperoleh nilai rata-rata 55,94 dengan kriteria kurang dan pada siklus II nilai rata-rata yang diperoleh meingkat menjadi 75,35 dengan kriteria baik.

Berdasarkan hasil dan kesimpulan penelitian yang diuraikan di atas, maka dalam usaha meningkatkan kemandirian anak melalui kegiatan practical life skill diajukan sejumlah saran. Saran tersebut diajukan kepada sekolah, guru dan peneliti berikutnya. (1) Bagi Sekolah; Pihak sekolah harus dapat menciptakan kondisi belajar yang memadai dengan menyediakan fasilitas dan sarana prasarana yang menunjang dalam pembelajaran khususnya dalam meningkatkan kemandirian penyediaan media, buku dan alat-alat media pembelajaran yang lain. (2) Bagi Guru;Guru harus lebih kreatif dalam memilih kegiatan atau media pembelajaran yang mudah didapat untuk meningkatkan kemandirian anak. Hasil penelitian menunjukkan bahwa kegiatan practical life skill dapat meningkatkan kemandirian pada kelompok A RA Yapata Al-Jawami Cileunyi Bandung. (3) Bagi Peneliti Berikutnya; Peneliti berikutnya dapat melakukan penelitian yang serupa dengan penelitian ini, tentunya dengan materi dan pendekatan yang berbeda

\section{Daftar Pustaka}

Arikunto, S. 2012. Penelitian Tindakan Kelas. Jakarta: PT Bumi Aksara

Aqib, Z. 2009. Penelitian Tindakan Kelas. Bandung: Yrama Widya

Hayati, T. 2013. Evaluasi Pembelajaran. Bandung: CV Insan Mandiri

Komala (2015) Mengenal dan Mengembangkan Kemandirian Anak Usia Dini Melalui Pola Asuh Orang Tua dan Guru. Tunas Siliwangi Volume 1 No. 1 Oktober

Permendiknas No. 58 Tahun 2009 tanggal 17 September 2009 Tentang Standar Pendidikan Anak Usia Dini

Permendiknas No. 20 Tahun 2003 tanggal 8 Juli 2003 Tentang Sistem Pendidikan Nasional

Purwanto, N. 2009. Prinsip-Prinsip dan Teknik Evaluasi Pengajaran. Bandung: PT Remaja Rosdakarya 
Rakhma, E. 2017. Menumbubkan Kemandirian Anak. Jogjakarta : CV. Diandra Primamitra Media

Rohmah, T. 2009. Meningkatkan Kemandirian Melalui Kegiatan Practical Life. Jurnal PG-PAUD, Universitas Negeri Surabaya.

Susenu, D. D. (2011) Hubungan Antara Pola Asub Orang Tua Dengan Kemandirian Anak Usia dini Pra Sekolah Di TK Aisyiah Mendungan Sukaharjo. Jurnal PG- PAUD, Volume 2, Nomor 1 April

Sanjaya, W. 2009. Penelitian Tindakan Kelas. Jakarta: Kencana

Sugiyono. 2015. Metode Penelitian Kuantitatif dan Kualitatif dan R\&D. Bandung: ALFABETA CV.

Sugiyono. 2018. Metode Penelitian Kombinasi (Mixed Methods). Bandung: ALFABETA CV

Syah, M. 2012. Psikologi Belajar. Jakarta: Raja Galindo Persada.

Yusuf, S. 2008. Psikologi Perkembangan Anak dan Remaja. Bandung: Remaja Rosdakarya

Zuriah, N. 2007. Metode Penelitian Sosial dan Pendidikan. Jakarta: PT Bumi Aksara. 